\title{
Retrograde single-balloon enteroscopy for the removal of a mollusc shell retained in the ileum of a patient with active Crohn's disease
}

A 33-year-old man with ileal Crohn's disease (Montreal classification A2, L1, B1) under adalimumab therapy presented to the emergency room with mesogastric abdominal pain, diarrhea, and vomiting during the previous 4 weeks. Physical examination showed no abdominal masses or peritoneal signs. Initial blood tests demonstrated leukocytosis and an increase of C-reactive protein. Abdominal computed tomography (CT) revealed a long segment of distal ileum, containing inflammatory stricturing disease and a radiopaque calcium-density foreign body, compatible with a mollusc shell (॰ Fig. 1).

Conservative management was initiated with antibiotics, intravenous corticosteroids, and fasting, increasing oral intake progressively. The symptoms markedly improved but a repeat CT scan 7 days later showed persistence of the shell. Consequently, the patient underwent retrograde single-balloon enteroscopy (Olympus Medical, Tokyo, Japan) for the endoscopic removal of the shell.

Endoscopic findings in the distal ileal mucosa included intense edema, longitudinal deep ulcers, and small aphthous erosions. At approximately $30 \mathrm{~cm}$ proximal to the ileocecal valve, a $20-\mathrm{mm}$ shell was visualized, causing partial luminal occlusion ( $>$ Fig. 2 a). The foreign body was anchored to the ulcerated ileal mucosa and was extracted successfully using a rat-tooth forceps without any complication ( $>$ Fig.2b, $>$ Video 1 ). Symptoms improved immediately after shell removal ( $\mathbf{F i g . 3}$ ), and the patient could be discharged after anal enteroscopy.

Therapeutic single-balloon enteroscopy can avoid the need for surgery in patients with Crohn's disease and intestinal obstruction due to a retained foreign body [1 -3]. The optimization of medical and endoscopic treatment avoided an ileocecal resection in an intensely active ileal Crohn's disease.
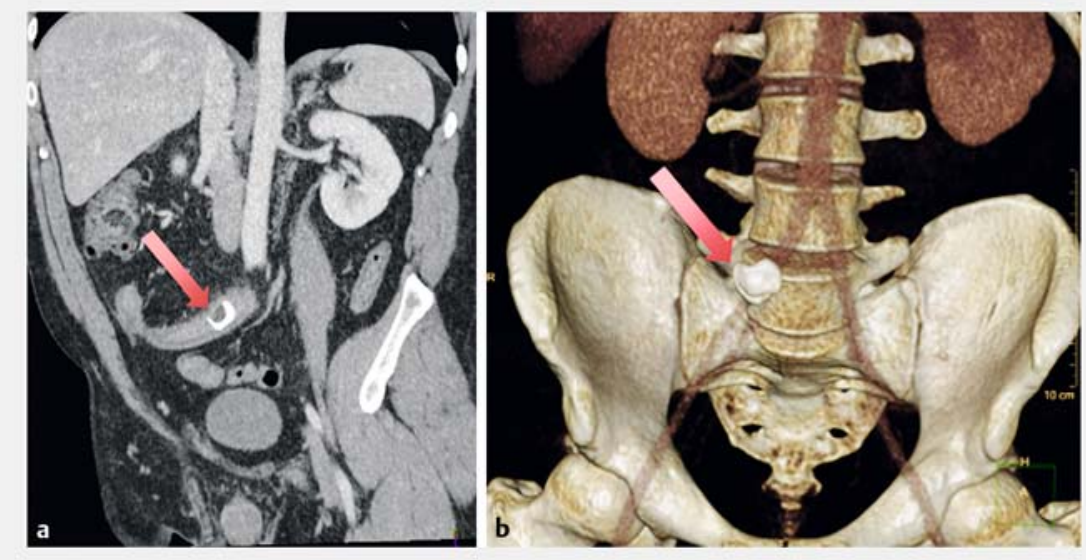

- Fig. 1 Initial computed tomography (CT) scan. a Sagittal view showed a hyperintense foreign body, suggestive of a mollusc shell, retained in the thickened wall of the distal ileum (red arrow). b CT with $3 \mathrm{D}$ reconstruction showed a mollusc shell in an intra-abdominal location (red arrow).
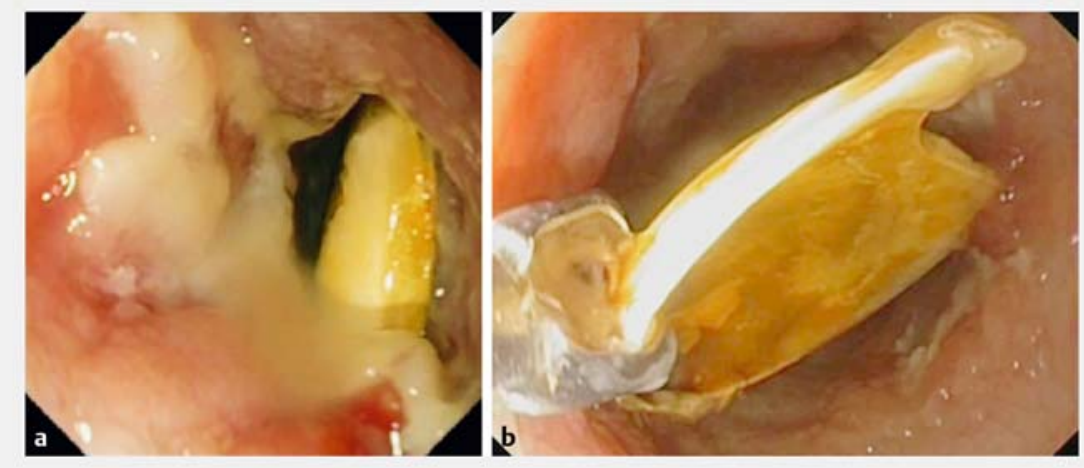

- Fig. 2 Single-balloon enteroscopy images. a The retained shell was seen within an ulcerated ileum. $\mathbf{b}$ The foreign body was carefully retrieved using grasping forceps.

Endoscopy_UCTN_Code_TTT_1AP_2AD

\section{Competing interests}

I. Marín-Jiménez has served as a consultant, advisory member, speaker, or has received research funding from Abbvie, Biogen, Chiesi, Faes Farma, Falk-Pharma, Ferring, Gebro Pharma, Hospira, Janssen, MSD, Otsuka Pharmaceutical, Pfizer, Shire, Takeda, Tillots, and UCB Pharma.

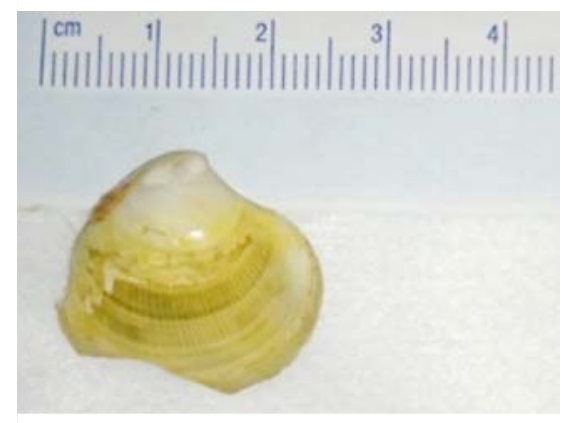

Fig. 3 The mollusc shell measured $25 \mathrm{~mm}$ in length. 


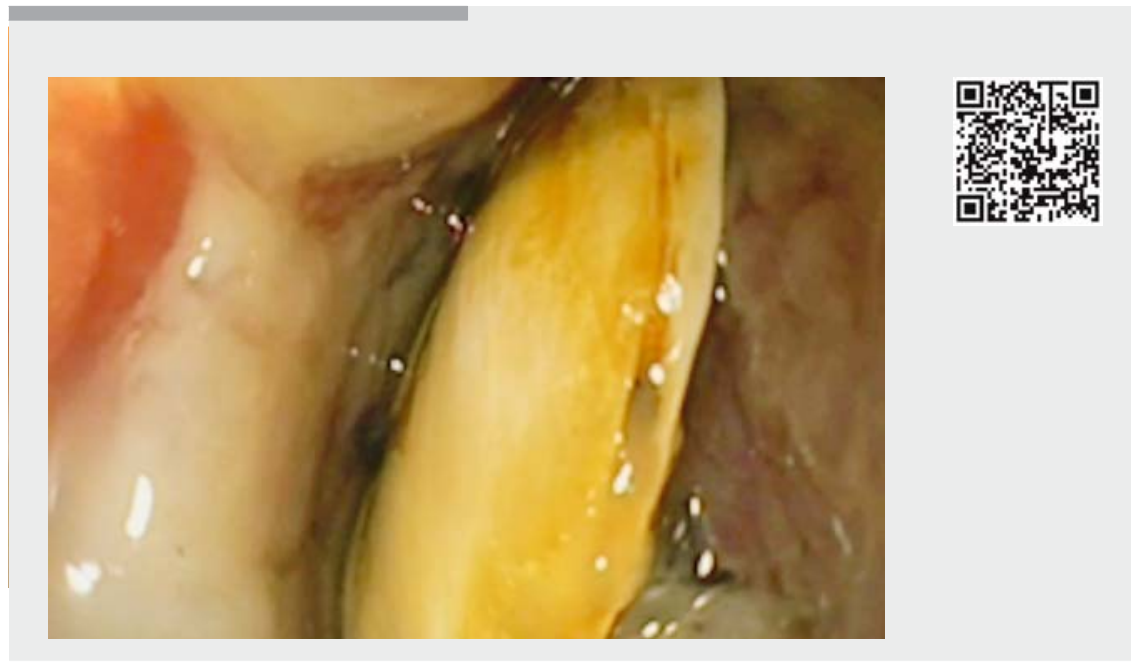

$\checkmark$ Video 1 Retrograde single-balloon enteroscopy for the retrieval of a foreign body retained in the distal ileum of a patient with severe Crohn's disease.

The authors

\section{Helena Martínez Lozano, Oscar Nogales} Rincon, Cristina Navarrete Marín, Andres Conthe Alonso, Javier García Lledó, Luis Menchén Viso, Ignacio Marín-Jiménez Department of Gastroenterology and Hepatology, HGU Gregorio Marañon, Madrid, Spain

\section{Corresponding author}

\section{Ignacio Marín-Jiménez, MD}

Department of Gastroenterology and Hepatology, HGU Gregorio Marañon, Street Doctor Esquerdo, 46, 28007 Madrid, Spain Fax: +34-91-629409193

ignacio.marin@salud.madrid.org

\section{Bibliography}

DOI https://doi.org/10.1055/a-0756-8062

Published online: 7.11.2018

Endoscopy 2019; 51: E14-E15

(c) Georg Thieme Verlag KG

Stuttgart · New York

ISSN 0013-726X

\section{ENDOSCOPY E-VIDEOS}

https://eref.thieme.de/e-videos

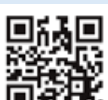

Endoscopy E-Videos is a free access online section, reporting on interesting cases and new

techniques in gastroenterological endoscopy. All papers include a high quality video and all contributions are freely accessible online.

This section has its own submission website at https://mc.manuscriptcentral.com/e-videos
[1] Fry LC, Akbar Q, von Gruchalla C et al. Endoscopic removal of a partial denture lodged in the jejunum, using single balloon enteroscopy. Endoscopy 2012; 44 (Suppl. 02): E236-237

[2] Prabhu A, Gonzalez S, Sarpel U et al. Retrograde single-balloon enteroscopy for the removal of an ileal foreign body. Gastrointest Endosc 2015; 81: 1277-1278

[3] Chang CW, Chang CW, Wang HY et al. Intermittent small-bowel obstruction due to a mobile bezoar diagnosed with singleballoon enteroscopy. Endoscopy 2011; 43 (Suppl. 02): E297 